\title{
製品機能をアップさせる二次加工技術
}

一接合・融着・多層化技術を中心に一

\section{2 章 高分子材料のレーザー接合技術}

\section{4 レーザー溶着装置の概略及び用途に応じた照射方法}

鈴 木 信 昭*

\section{1 .レーザー溶着の基本とその特長}

\section{1 はじめに}

既知のことではあるが，レーザー溶着装置について述べ る前にレーザー溶着の基本を再確認する意味でも此処に レーザー溶着の原理についてあらためて記しておく.

\section{2 レーザー溶着とは}

レーザー溶着の基本はあくまでも重ね合わせ溶着である (突き合わせ溶着には不向きである). 図1のように部品 $\mathrm{A}$ と部品 $\mathrm{B}$ が重なり合うように位置し, 部品 $\mathrm{A}$ がレー ザー透過体であり，部品 B がレーザー吸収体であること が基本である．部品 $\mathrm{B}$ は，レーザーを吸収するためにカー ボン等で着色されている，照射されたレーザーは，部品 $\mathrm{B}$ の表面で吸収され熱エネルギーとなって部品 B の表層部 を溶融する，一方，予部品 A と B を上下から加圧して 密着させることにより部品 $\mathrm{A}$ も熱伝導によって溶融され, 部品双方が溶融した時点で溶着完了となる.

\section{3 レーザー溶着の特長}

レーザーによる樹脂溶着は，他の溶着工法と比較すると まだまだ歴史が浅くその可能性も未知数なところが多いが， 次のような点が特長として挙げられるであろう。

a．部品に振動を与えることのない溶着ができる.

b．部品への熱ストレスや熱ひずみを最小限に抑えた溶着 ができる。

c . 振動溶着や超音波溶着と比較して, 溶着界面を単純化 することができる。(平坦でよいー図 2 参照)

d．非接触である.

e. 再現性に優れる.

f ．高強度で密閉性に優れた溶着ができる.

$\mathrm{g}$ ，バリのない見た目にきれいな溶着ができる.

h. 粉塵のない溶着ができる。

\section{4 将来性}

従来工法である振動溶着，超音波溶着，熱板溶着等と比

\footnotetext{
Suzuki, Nobuaki

株パーカーコーポレーション 機械開発課

東京都中央区日本橋人形町 2-22-1（ ₹103-8588） 2008.1.9 受理
}

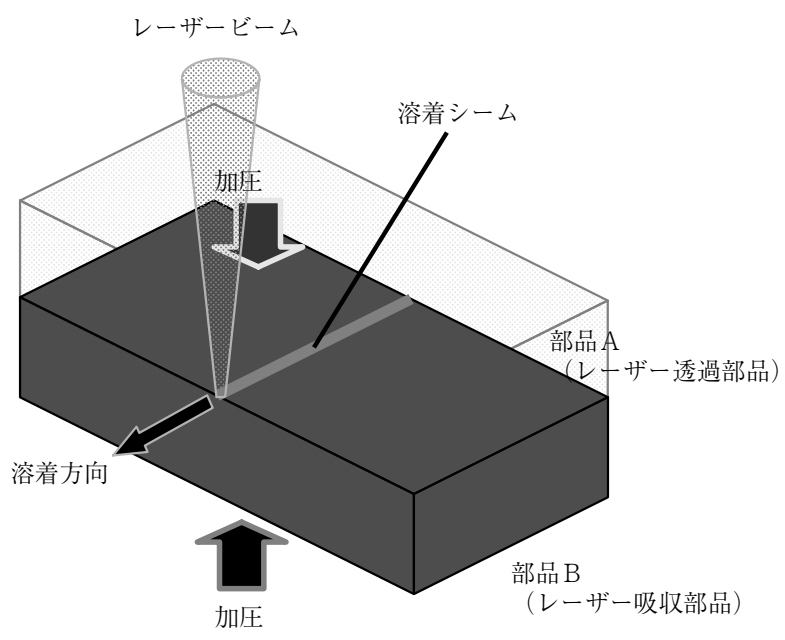

図 1 レーザー溶着の基本原理

較して，それらには無い特長を有することから，その未知 なる将来性が期待される工法であり，具体的には次のよう なアプリケーションへの応用が期待されるであろう.

a . 振動が無い $\rightarrow$ 電子部品のハウジング溶着

b．熱ストレスが無いい電子部品のハウジング溶着

c．粉塵がない $\rightarrow$ 医療部品の溶着

d . バリが無く見た目に優れる e . バリが無く振動・熱ストレスが無いーマイクロ流体デ バイス等の溶着

\section{2.レーザープラスチック溶着装置}

\section{1 装置の基本構成}

装置は，(1)レーザーモジュールを中心に，(2)レーザーパ ワーサプライ (3)チラー（空冷式若しくは水冷式）(4)光学 系 (5)クランプ装置 (6)コントロール系（制御用ソフトウェ アを含む PC 等)，そしてそれを一つにまとめるハウジン グから構成される。（図 3 )

\section{2 レーザーモジュール}

4 5 年前までは, LD（レーザーダイオード）の出力不 足の問題もあり，YAGレーザーも使われていた．現在は (1)その出力も格段にアップしたこと，(2)比較的に安価であ 


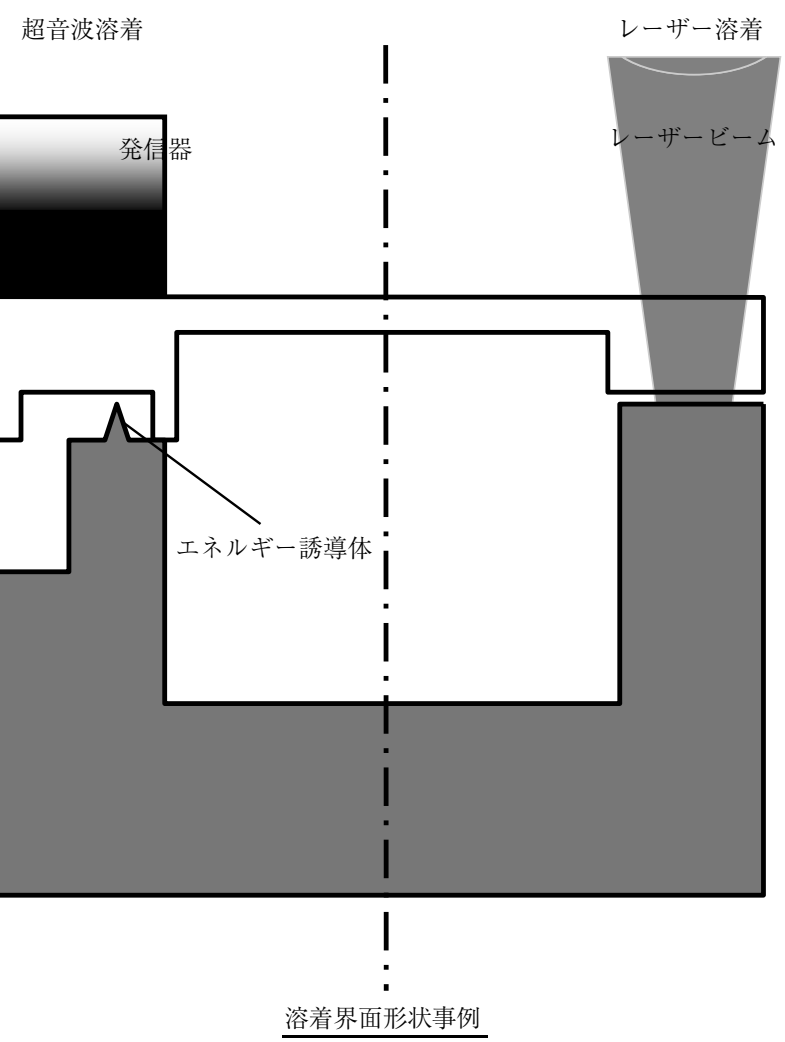

図 2 溶着工法よる溶着界面形状比較

ること, (3)サイズもコンパクトでメンテナンスも他のレー ザー $\left(\mathrm{CO}_{2}\right.$ や YAG $)$ と比較すると特に必要としないこと. 以上から高出力のファイバーカップリング式 LD（レー ザーダイオード）がメインとして使用される. 波長は主に $808 \mathrm{~nm}$ と $940 \mathrm{~nm}$ であるが, $940 \mathrm{~nm}$ の方が各樹脂に対し てレーザー透過性に優れるため, $940 \mathrm{~nm}$ を使用すること が多い. 出力は, 用途によって異なるが, $30 \mathrm{~W} \sim 300 \mathrm{~W}$ 程度が一般的であろう。

\section{3 レーザーパワーサプライ}

通常は,この中にレーザーモジュールが組み込まれ, レー ザー出力を管理すると共に, チラーと連動し, レーザーモ ジュールの温度管理, エラー表示等, レーザーを集中管理 する.

\section{4 光学系}

詳しくは, 後述の各種照射法にて説明するが，この光学 系によって，レーザービームを集光する．照射幅等はこの 光学系によって決定される.

\section{5 クランプ装置}

装置構成部品は, 全て重要ではあるが，ある意味本装置 が一番重要な構成要素と言える. 部品に応じたクランプ装 置を開発しなければならないからである。溶着の成否は, 如何に上部部品と下部部品を密着させるかに掛かっている と言っても過言ではない.しかしながら，各種形状へのク ランプ装置の対応には限度があるので，可能であれば，部 品形状をクランプし易い形状に設計することも一つの選択 である。一例ではあるが, 下図（図 4）に2 次元形状部品 に対応したクランプ装置例を示す。

\section{6 チラー}

レーザーモジュールのメーカーにもよるが，一般的に

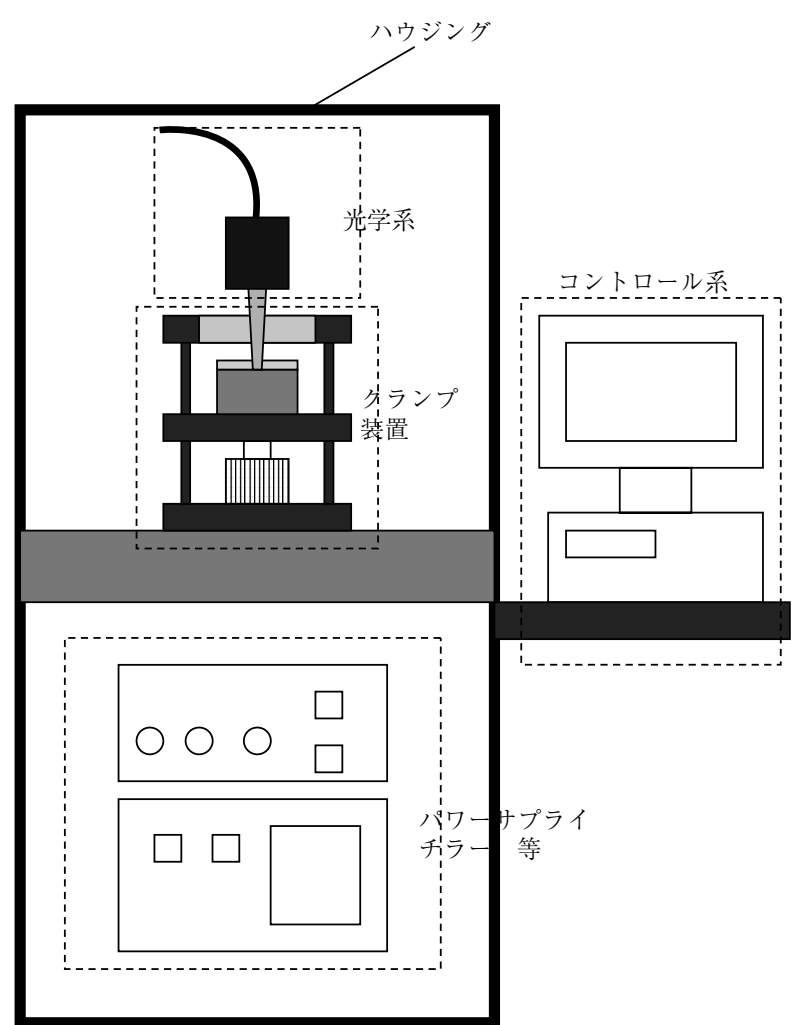

図 3 レーザー溶着装置

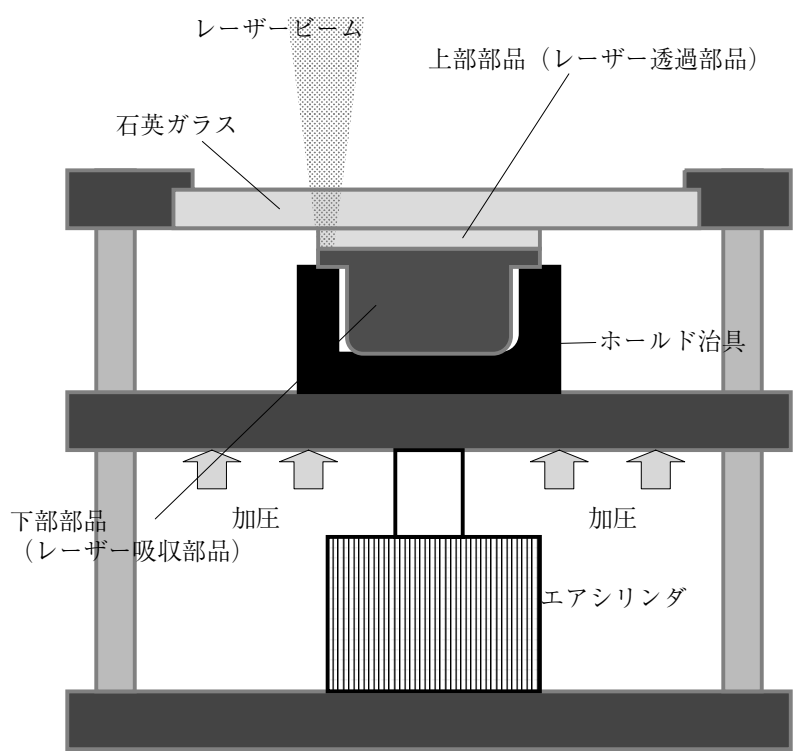

図 4 クランプ治具

は, $50 \mathrm{~W} \sim 75 \mathrm{~W}$ 程度までは空冷式, $100 \mathrm{~W}$ 以上は水冷式 のチラーを使用する。

\section{7 コントロール系}

PC (ソフトウェア）で管理する場合は, (1)ティーチン グ (軌跡) (2)レーザー出力 (3)走査スピード (4)クランプ圧 等を一括管理する。

\section{8 ハウジング}

レーザー自体は，レーザー安全基準のクラス 4 に該当し 大変危険なため, ワーク出し入れの為の前面扉にインター ロックを取り付け，空にはレーザー遮光空を採用するなど， レーザー照射中にレーザー光が装置外部に漏れない工夫が 


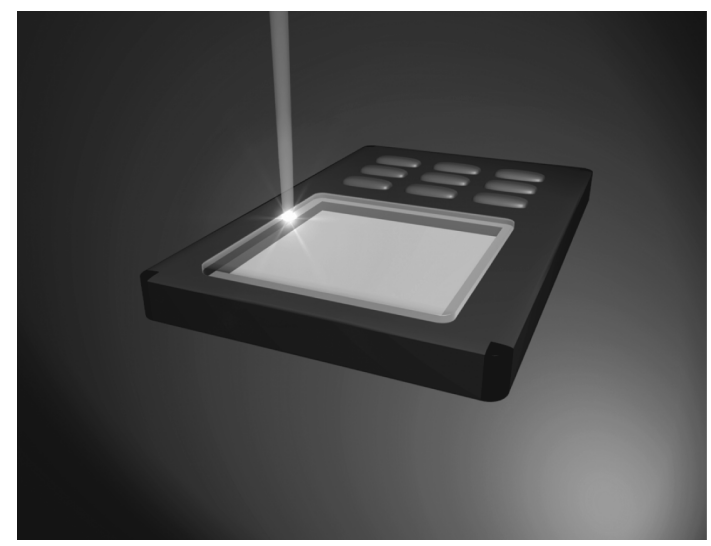

図 5 軌跡照射

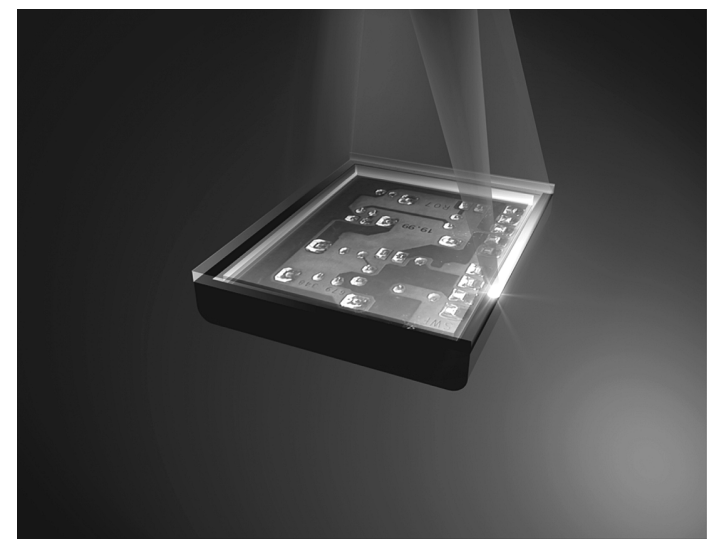

図 7 ガルバノ照射

必要である.

\section{9 オプション}

生産機としてより効率的且つ有効に使用するために，便 利なオプションを幾つか取り上げる.

a.ビジョンシステム

一般的にはレーザーモジュール内蔵のガイド光を目視に てティーチングの設定を行うが，ょり正確且つ確実に ティーチングを行うためにCCD カメラ等をレーザーの同 軸上に配置することで，モニター上で溶着部品の真上から 見ながら，ティーチングすることができる.

b. パイロメーター (温度調節機能)

赤外線温度センサーを搭載し, PID 制御にて温度管理を 行うことができる。（但し上部部品の透過率が $25 \sim 30 \%$ 以 上の場合）

c. $\mathrm{CAD} \rightarrow \mathrm{CNC}$ 変換ソフトゥェア

$\mathrm{CAD}$ ファイル $(\mathrm{dxf}$ ファイル) を $\mathrm{CNC}$ プログラムに変 換するソフトウェア．複雑なティーチングの場合は，かな り有効である。

\section{3. 各種用途に応じた照射方法}

部品の形状や大きさ, 溶着部位, 生産夕クト等によって レーザーの照射方法もまた重要なファクターの一つである. 以下 6 種類のアプリケーションに応じた照射方法を説明する.

\section{1 軌跡照射（図 5)}

標準的なレーザーの照射方法. スポットビームを溶着軌 跡に沿って動かし溶着する．溶着軌跡やレーザービーム径

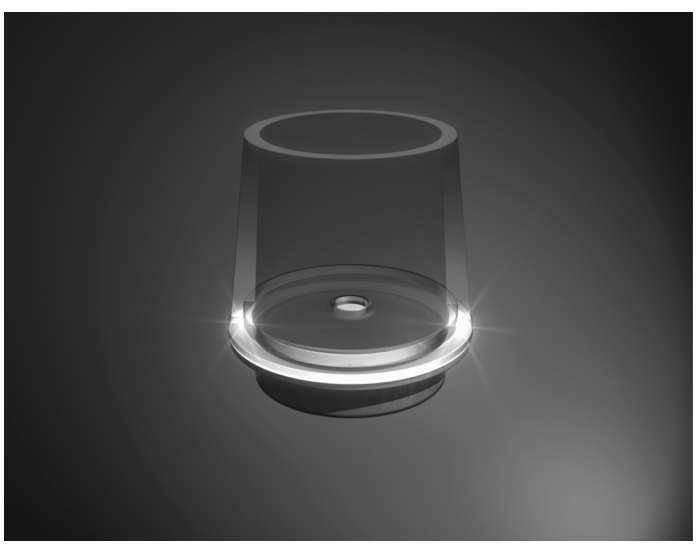

図 6 同時照射

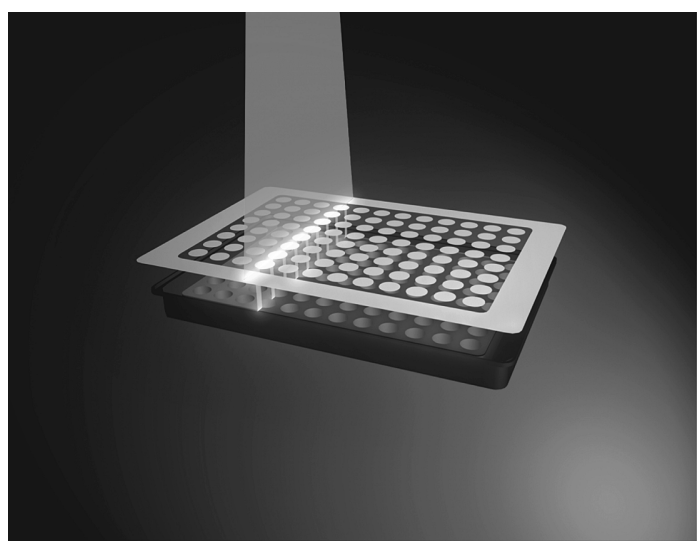

図 8 マスク照射

は簡単に変更できるので，一つの装置で様々な形状の部品 を溶着したり，比較的小型の部品を溶着したりするには有 効的である. 主に試作・開発若しくは，少量生産向きの照 射方法である。また，バリを最小限に抑えたい時は有効な 手段である.オプションとして, ビジョンシステムやパイ ロメーターを採用する場合もこの照射方法を選定する.

\section{2 同時照射（図 6)}

スポットビームを, 光学系で照射したい形状（例えば円 やラインなど）にシェーピングして溶着する．全体を同時 に加熱するため軌跡照射と比較して溶着時間を大幅に短縮 できるのが特長である．また，同時溶融のため若干の沈み 込みが期待でき，バリが発生するため，ギャップを埋める 溶着が可能である. 複数のラインビームを並べることで, ある程度の大きさの部品も同時溶融が可能である. 光学系 が一つの部品専用となるため, 量産向きである.

\section{3 スキャン照射（図 7)}

スキャナミラーでレーザービームを軌跡に沿って高速回 転させ，溶着シーム全体を同時に溶融する．光学系による 同時照射と違いプログラムによる軌跡変更が可能なのが最 大の特徵であるが，スキャナミラーが高額なことと小型の 部品のみの対応になることが難点である．同時照射と同様 に部品の沈み込みによるバリが発生するため, ギャップを 埋める溶着が可能である. 他品種少量生産にも, また大量 生産にも対応が可能である.

3.4 マスク照射(スイス,ライスター社特許技術一図 8) レーザー光源と溶着対象部品間にマスクを挿入して行う 


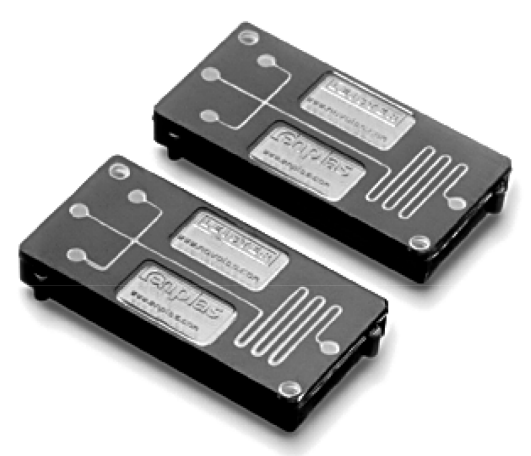

図 9 マイクロ流体デバイス

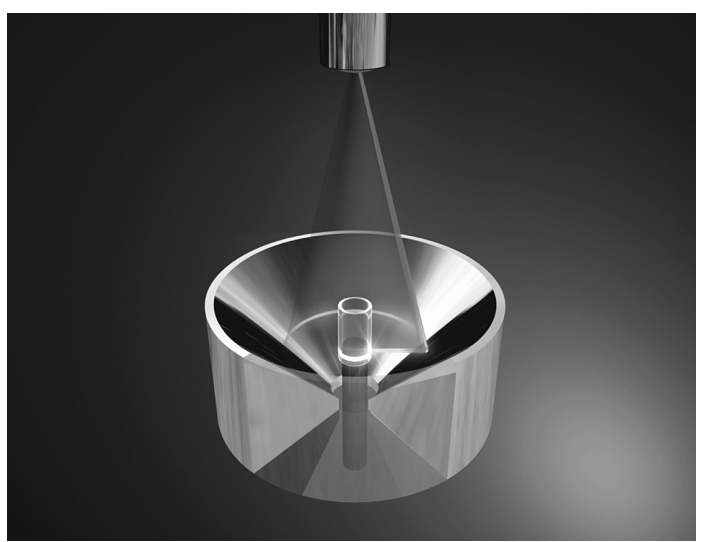

図 10 ラジアル照射

溶着手法である．接合部分全体に平行ビームを移動させて 溶着を行い，レーザー光はマスクで遮られていないワーク 部分にのみ照射される. マスクを使用することでミクロン 単位の非常に小さな構造を溶着することが可能になる。 こ の溶着手法では, 非常に複雑な部品構造の溶着が可能であ る。例えば，幅の異なる直線や曲線，また面を混在させて 一度に溶着することができ，マイクロ流体デバイス（図 9） やマルチウェルアレイの溶着に最適である.

\section{5 ラジアル照射（図 10)}

円筒形部品溶着専用の技術で, スキャナミラーで回転さ せたレーザー光を部品の円周上に $360^{\circ}$ 均一に照射する. 接合部材同士は圧入に近い状態とし, 溶着の際に必要な密

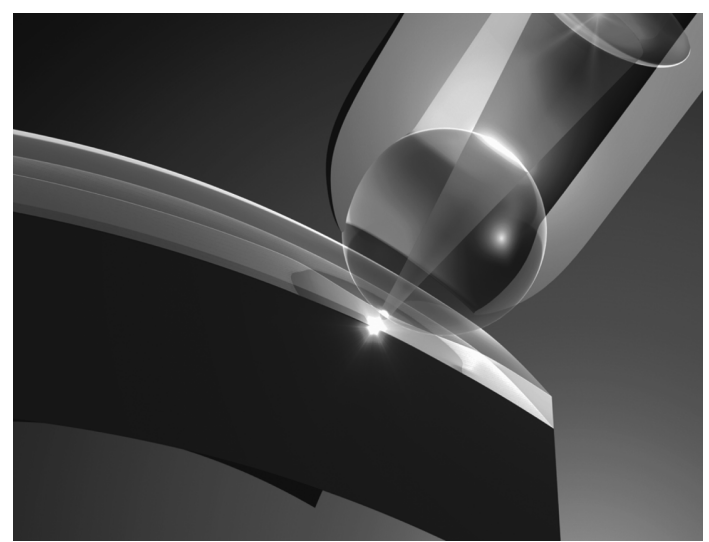

図 11 Globo（グロボー）照射

着度を確保する. 溶着中は, 部材は固定されており, 部品を 回転させる必要が無いため, 高生産性が期待できる.

3.6 Globo (グロボー) 照射（スイス,ライスター社 特許技術一図 11)

Globo 溶着は，摩擦無く動くエアベアリング式のガラス 球を通過したレーザー光を接合界面上に集光させ，軌跡を 描いて溶着する手法である。 ガラス球は, 集光のみではな くクランプ治具として部品の加圧の役割も果たす。ガラス 球は，部材表面上を転がりながら接合平面上のポイントを 連続して加圧する。これにより, 接点圧力が印加されたポ イントにのみレーザー光が照射される. ガラス球がクラン プ装置と同じ加圧役割も果たすことで $2 \mathrm{D}$ 部品ばかりでな く, $3 \mathrm{D}$ 形状部品にもレーザー溶着の適用範囲が広がる. 広範囲のシート上の溶着や, 自動車のテールランプ等に適 している.

\section{4.まと め}

レーザーによる樹脂溶着は，まだまだ歴史が浅く，従っ て装置も発展途上段階にあると考える。しかしながら, 現 状の様々なクランプ装置や照射手法の組み合わせによって も，その可能性は未知数であり，今までの溶着手法では為 し得なかったアプリケーション開発によって, レーザー溶 着装置の更なる発展が見込まれるであろう。 